\title{
PROBLEMATIKA HUKUM KELUARGA: ANTARA FENOMENA DAN PARADIGMA KITAB KLASIK
}

\author{
Jaenal Aripin \\ Himpunan Ilmuwan dan Sarjana Syariah Indonesia (HISSI) \\ Jl. Ir. H. Juanda No. 95 Ciputat, Jakarta \\ E-mail: j_aripin72@yahoo.co.id.
}

\begin{abstract}
Problems with Family Law: The Phenomena and the Paradigm of Classical Texts. There are many factors that can trigger the emergence of family problems. One factor that is especially influential is diminished adherence to religious values, in which husbands, wives and children forgo using these values as the foundations upon which to live. If that is the cause of family problems, returning to religious values can provide one way of solving them. But these values aren't problem-free either, given that religious texts, especially classical religious texts, seem misogynistic and too discriminatory towards women, limiting their roles only to inside domestic matters. Because of these problems, this article argues that creating a harmonious life between husband and wife must be guided by principles promoting equal rights and valuing each spouse's role equally.
\end{abstract}

Keywords: family law, religious value, classical text

Abstrak: Problematika Hukum Keluarga: Antara Fenomena dan Paradigma Kitab Klasik. Banyak faktor yang menyebabkan munculnya masalah di dalam keluarga. Salah satu yang kuat pengaruhnya adalah karena lunturnya pengamalan nilai-nilai agama, yang tidak lagi dijadikan landasan dalam berpijak, baik oleh suami, isteri maupun anak. Karena itu, kembali kepada nilai-nilai agama menjadi salah satu solusi tawarannya. Namun bukan tanpa masalah, mengingat teks-teks keagamaan khususnya klasik, kadang terkesan mesoginis dan terlalu mendeskriminasi kaum perempuan dan membatasi peran mereka hanya dalam urusan domestik. Karenanya, prinsip-prinsip yang mengedepankan persamaan hak dan saling menghargai peran, harus dipedomani guna menciptakan kehidupan harmonis antara suami isteri.

Kata Kunci: hukum keluarga, nilai keagamaan, teks klasik

\section{Pendahuluan}

Fenomena keretakan rumah tangga yang akhirakhir ini semakin merata di kalangan publik figur, ${ }^{1}$ ditambah publikasi media yang melampaui batas wajar, tentu menjadi kegelisahan tersendiri bagi pemerhati perkembangan masyarakat. Pasalnya, keluarga merupakan tahap pendidikan pertama bagi sebuah generasi. Kondisi yang demikian buruk menjadi ancaman utama bagi keberlangsungan sebuah generasi yang diharapkan lebih baik dari generasi sebelumnya. Hal itu tercermin dalam kenyataan bahwa budaya

Naskah diterima: 23 Januari 2012, direvisi: 16 Mei 2012, disetujui untuk terbit: 30 Mei 2012.

${ }^{1}$ Sepanjang akhir tahun 2011 sampai awal tahun 2012 ini saja sudah ada paling tidak enam pasangan publik figur yang mengajukan perkara perceraiannya di Pengadilan Agama Jakarta Selatan, yakni; Theresia Ebenna Ezeria Pardede dengan Eka Nugraha, Nova Eliza dan Nirwan Suwarso, Ratu Felisa dan Franciscus Emmanuel, Prisia Nasution dan Ananda Haris Siregar, Peggy Melati Sukma dan Wisnu Tjandra serta Bernaldi Kadir Djemat dengan Feni Farnita. kekerasan tidak hanya terjadi pada elit-elit politik dan masyarakat ekstremis pada suatu aliran keagamaan atau pemikiran, tetapi juga terjadi pada kalangan pelajar. $^{2}$

Kemungkinan paling pahit dari semua fenomena di atas adalah runtuhnya sebuah peradaban. Seperti dinyatakan oleh Husayn Amîn, keruntuhan sebuah peradaban selalu dimulai oleh rusaknya hubungan rumah tangga. ${ }^{3}$ Tentu tidak berlebihan jika kesimpulan serupa itu mencuat karena rumah tangga sebagai pertahanan pertama sudah rapuh. Sementara itu, budaya di luar rumah tidak bisa lagi dijamin lebih baik dari dalam rumah. Ia mencontohkan di Amerika,

\footnotetext{
${ }^{2}$ Kekerasan di kalangan pelajar baru-baru ini terjadi di Bali, yakni sekumpulan wanita yang menamakan dirinya sebagai geng motor Cewek Macho Performance (CMP) menganiaya salah seorang anggotanya (AK) yang baru berusia 16 tahun. Tempo Interaktif, 8 Februari 2012. Kompas 1 Oktober 2010 juga melaporkan bahwa mayoritas anak geng motor adalah lulusan SD-SMP yang kerap melakukan kekerasan bahkan pemerasan terhadap masyarakat umum.

${ }^{3}$ Husayn Amîn, al-Mar'ah bayna al-Syâri' wa al-Bayti, (Bayrût: Dâr al-Syurûq, 1999), h. 83.
} 
terdapat 51\% keluarga yang retak, $2 \%$ di antaranya anak-anak diasuh oleh bapaknya dan 9\% oleh ibunya. Bahkan dalam laporan selanjutnya, angka keretakan rumah tangga meningkat mencapai angka $70 \% .{ }^{4}$ Semua itu menjadi bukti kuat bahwa Amerika sudah bobrok sehingga tak perlu diherankan jika kebudayaan dan peradaban Amerika akan segera runtuh.

Sangat disayangkan jika prediksi itu bisa terjadi pada negara-negara yang mayoritas masyarakatnya adalah Muslim. Dalam budaya global seperti saat ini, ketakutan semacam itu bukan hanya asumsi atau sebatas prediksi. Dapat diperhatikan betapa dinamika sosial dalam masyarakat sudah bergeser ke arah budaya barat (baca: Amerika) yang mengagungkan kebebasan dalam semua aspek kehidupan. Pada titik tertentu, kebebasan memang menjadi piranti lunak bagi perkembangan dan pengembangan budaya menuju titik yang lebih sempurna. Namun, dalam kebanyakan aspek lainnya, kebebasan tidak lebih sebagai ancaman. Sebab, ketika semua diijinkan, banyak nilai-nilai masyarakat kehilangan daya ikatnya dalam kehidupan. Kenyataan di atas adalah salah satu buktinya.

Pentingnya harmoni dalam keluarga menjadi perhatian dalam Islam. Sebab, bagaimana pun manusia adalah makhluk hidup yang berbudaya, dan hanya bisa bertahan hidup dengan modal budayanya. Dalam hal ini, ia berbeda dari kebanyakan makhluk hidup lain yang hanya mengandalkan kemampuan fisik dalam menjawab tantangan seleksi alam. Manusia tidak diciptakan dengan kemampuan semacam itu. Walau demikian ia memiliki kelebihan yang tidak ada pada makhluk hidup lainnya, akal. ${ }^{5}$ Akallah yang

\footnotetext{
${ }^{4}$ Untuk konteks Indonesia, keretakan rumah tangga bisa dilihat dari indikator angka perceraian yang terjadi, karena perceraian bisa terjadi salah satunya akibat dari keretakan rumah tangga. Untuk menunjukkan tingginya perceraian sebagai akibat adanya keretakan rumah tangga, contoh di wilayah Kota Bandung saja, angka perceraian yang terjadi pada tahun 2003 sebanyak 1.712, 2004; 1.741, 2005; 1.867, 2006; $1.934,2007 ; 2.085,2008 ; 2.631$, dan 2009; 3.321. Angka tersebut terus meningkat dari tahun ke tahun. Baca selengkapnya di http://m. pikiran-rakyat.com/node/86262 Pada Hari Senin Tanggal 10-01-2011 dan http://bataviase.co.id/detailberita-10550739.html Pada Hari Senin Tanggal 10-01-2011.

${ }^{5}$ Dalam kitab al-Tárîfât, al-Jurjâni mendefinisikan, "Akal adalah substansi jiwa yang diciptakan Allah Swt. yang berhubungan dengan badan manusia. Akal juga berarti cahaya (nûr) dalam hati untuk mengetahui kebenaran dan kebatilan. Ada pula yang mengartikan akal dengan substansi yang murni dari materi yang berhubungan dengan badan yang mengatur dan mengendalikan. Menurut pendapat lain, akal ialah suatu kekuatan bagi jiwa berpikir (al-nafs al- 'aqliyyah) berbeda dengan jiwa berpikir, sebab pelaku perbuatan ( $f a \hat{~} i l)$ sebenarnya adalah bagai tukang potong. Ada pula yang menyamakan arti al-'aql, al-nafs dan al-dzihn. Kecuali itu, dinamakan al-aql karena ia bisa menangkap (al-mudrikah), dinamakan al-nafs karena ia pengendali (mutasharrifah), dan dinamakan al-dzihn karena ia siap untuk menangkap sesuatu (musta iddât li l-idrâk)". Al-Jurjâni, Kitab al-Tárîfâtt, (Bayrût: Maktabah Libanon, 1969), h. 157. Dari kutipan tersebut dapat disimpulkan
}

menempatkan keluarga menjadi kebutuhan primer bagi pertumbuhan manusia.

Bayi binatang, misalnya, hanya membutuhkan bimbingan induknya dalam waktu singkat, sekadar untuk memastikan bahwa si bayi sudah memiliki kemampuan bertahan hidup, menghindari ancaman dan bisa mencari makan. Selepas itu, ia sudah menjadi binatang dewasa yang bebas. Sedang bayi manusia membutuhkan bimbingan yang lebih lama. Kemampuan yang dibutuhkan manusia tidak hanya insting seperti pada binatang, dia membutuhkan kemampuan berbahasa untuk berkomunikasi, memiliki pengetahuan untuk menemukan model kehidupan yang lebih baik dan lebih nyaman. Itu pun bergantung pada kemampuan otak dan akal mereka dalam menangkap pelajaran dari keluarga dan lingkungannya. ${ }^{6}$

Jean Peaget menegaskan bahwa kemampuan akal manusia berkembang secara bertahap. Pada tiap fasenya itulah bimbingan kedua orang tua dibutuhkan sebagai asimilasi dan adaptasi bagi sang anak, di samping menjaga kesehatan dan keamanan bayinya. ${ }^{7}$ Oleh karena itu, kelanggengan rumah tangga sangat penting demi kelancaran transmisi budaya dan proses pertumbuhan akal sang anak. Sebab, pada tahap belajar, anak hanya bisa meniru gejala apa pun yang sering dilihatnya. Keretakan rumah tangga dan pertikaian antara ayah dan ibunya menjadi situasi yang tidak kondusif bagi pertumbuhan itu, sekaligus menjadi pelajaran baginya, bukan sebagai pelajaran yang mampu ia kenali sebagai cara negatif yang harus ia hindari, melainkan terekam

bahwa, akal merupakan substansi yang sangat urgen dalam diri manusia, ia sebagai cahaya (nur) dalam hati yang berguna untuk mengetahui kebenaran dan kebatilan, mengatur dan mengendalikan jasmani, dan akal adalah alat pengatur bagi jiwa, sebagai pengendali, pengontrol hawa nafsu. Akal inilah yang disebut juga dengan akal "âlamî" atau akal "teoretis". Yang jelas, dalam pengertian Islam akal bukanlah otak (al-dimâgh). Menurut Syihâb al-Dîn Muhammad ibn Aḥmad Abi alFath al-Abshîhî, akal bukanlah otak, tetapi hanya esensi materi yang diciptakan oleh Allah Swt., dalam otak, ibarat cahaya yang terdapat dalam hati yang kedua-duanya mempunyai potensi untuk mengetahui sesuatu yang nampak dan meneropong sesuatu yang tidak nampak tetapi merupakan daya pikir yang terdapat dalam jiwa manusia. Daya yang dalam Alquran digambarkan memperoleh pengetahuan dengan memperhatikan alam sekitarnya. Syihâb al-Dîn ibn Aḥmad Abî al-Fath al-Absîhî, Al-Mushtathraffi Kull Fan Mustazraf, Juz I , (Bayrût: Dâr alKutub al-'Ilmiyyah, 1993). Selain itu, akal pikiran juga berarti potensi gaib yang tidak dimiliki oleh makhluk lain yang mampu menuntut pemahaman diri dan alam. Ia juga mampu melawan hawa nafsu. Sehingga, dengan akal yang diperankannya manusia akan bersikap bijaksana, bisa menyampingkan hal-hal yang berkenaan dengan hawa nafsu. Dan mampu berpikir secara cepat dan cermat sesuai dengan tuntunan dan pertimbangan matang. Morteza Mutahari, The Human Being in The Qur 'an, (Teheran: Islamic Propogation Organitation, 1984), 45).

${ }^{6}$ Husayn Amîn, al-Mar'ah Bayna, h. 57-58.

${ }^{7}$ C. George Boore, Sejarah Psikologi dari Masa Kelahiran Sampai Masa Modern, terj. Abdul Qadir Saleh, cet. II, (Yogyakarta: Primasophie, 2007), h. 484. 
menjadi mental, seperti kekerasan yang muncul di kalangan remaja. Fenomena itu tidak lain adalah cerminan realitas kehidupan dalam rumah tangganya.

Di samping sebagai kebutuhan asasi seperti diuraikan di atas, kehadiran keluarga adalah pemenuhan akan kebutuhan psikologis bagi manusia dalam perjalanan hidupnya. Al-Thabarî menjelaskan firman Allah dalam surah al-A'râf [7]: 189 bahwa keluarga (pasangan) ibarat rumah dan pelindung bagi anggota di dalamnya satu sama lain. Kategori pelindung dalam hal ini tidak semata dalam arti proteksi dari ancaman faktor eksternal, seperti juga dialami oleh binatang, tetapi juga mengenai kegelisahan psikologis. Dengan kata lain, keluarga adalah tempat mencurahkan semua keresahan dan obat yang tepat untuk melepaskan semua beban perasaan. ${ }^{8}$

\section{Fikih Keluarga: Cenderung Patriarkal?}

Kembali pada persoalan, keretakan rumah tangga dapat diatasi dengan kembali pada nilai-nilai agama mengenai persoalan rumah tangga. Kesimpulan ini sekaligus menegaskan bahwa masa lalu dengan berlakunya nilai agama lebih baik daripada masa kini dengan segenap kemajuan dan perkembangan masyarakatnya. Pasalnya, perkembangan pengetahuan dan teknologi yang ada tidak menjadi pemicu bagi perkembangan masyarakat ke arah yang lebih maju. Justru kenyataan yang terjadi adalah kebalikannya.

Sayangnya, upaya kembali pada nilai-nilai agama bukanlah upaya tanpa kendala mengingat banyaknya tuduhan bahwa nilai-nilai agama dalam hal ini terkesan misoginis dan terlalu mendiskriminasi kaum perempuan, di samping juga terkesan membatasi peran mereka semata dalam urusan domestik. Para kritikus mendasarkan tuduhan ini pada ayat-ayat Alquran mengenai pembagian harta waris, di mana keturunan perempuan memperoleh separuh bagian keturunan laki-laki. Selain itu, banyak Hadis yang menegaskan posisi perempuan hanya sebagai pelayan dan harus mengabdi kepada suaminya. ${ }^{9}$

Kesimpulan mereka juga dikuatkan oleh pelbagai tulisan ulama Muslim mengenai etika dan kewajibankewajiban yang harus dilakukan oleh seorang perempuan kepada suaminya. Paling tidak, karya 'Âdil Fathî 'Abd Allâh cukup menggambarkan hal itu melalui delapan poin yang harus dipenuhi seorang istri. Berikut akan diuraikan empat poin yang disebutkan 'Âdil dalam bukunya, Kayfa taksabina qalba zawjaki wa turdlinna

\footnotetext{
${ }^{8}$ Abû Ja’far al-Thabarî, Jâmi’u al-Bayân fî̀ Ta' wîl al-Qur'ân, j. III, (Bayrût: Mu`assasah al-Risâlah, 2000), h. 491.

9 Budy Munawar Rachman, "Islam dan Feminisme dari "Sentralisme" kepada Kesetaraan", makalah tidak diterbitkan. h. 2.
}

rabbaki. ${ }^{10}$

Pertama, banyak mengeluh bisa mematikan hati. Menurut dia, ketika seorang istri sedang marah kepada suaminya, yang harus ia lakukan adalah meminta maaf kepada sang suami karena dengan tindakan tersebut sang suami akan memberinya semangat yang membesarkan hatinya. Sebaliknya, marah dan mengeluhkan kondisi suaminya adalah pemicu munculnya perceraian.

Kedua, istri yang tidak mensyukuri kehadiran suaminya berarti tidak bersyukur kepada Allah. Pada poin ini seorang istri harus berbaik sangka dan tidak mengeluh atas semua yang diberikan suami kepada diri dan keluarganya.

Ketiga, istri tidak boleh cemburu atas perilaku suami karena cemburu yang demikian dibenci oleh Allah. Menurut dia, hakikat pernikahan adalah seorang perempuan memilih seorang laki-laki yang ia percaya untuk menjadi suaminya. Karena itu, ia tidak berhak merasa cemburu kepada suaminya. Bahkan, untuk menjaga keharmonisan keluarga, perempuan harus menjaga diri dari orang lain yang bisa membuat suaminya cemburu. 'Âdil menengarai kecemburuan seperti ini yang kerap menyebabkan keretakan rumah tangga.

Keempat, taat kepada suami bisa memadamkan murka Allah. Dalam hal ini Âdil mengutip Hadis bahwa pahala perempuan yang patuh kepada suaminya setara dengan pahala berjihad di jalan Allah. Bahkan, ia berkesimpulan bahwa suami adalah surga sekaligus neraka bagi seorang perempuan. Tolok ukurnya adalah kepatuhan sang istri kepada suaminya. Secara kesuluruhan karya 'Âdî ini merupakan etika yang ditujukan kepada kaum perempuan, bahkan terlihat dari judul buku tersebut.

Karya semacam ini tidak sedikit jumlahnya, bahkan terdapat karya seorang ulama pribumi dengan muatan yang tidak jauh berbeda. Syaykh Nawawî al-Jâwî atau populer dengan julukan al-Bantanî

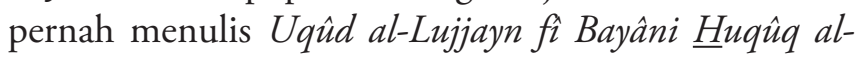
Zawjayn ${ }^{11}$ sekaligus anotasi yang ia buat sendiri. Karya tersebut mengandung tiga pasal mengenai hubungan keluarga yang $10 \%$ di antaranya menjelaskan seputar kewajiban suami kepada istrinya. ${ }^{12}$ Adapun yang tersisa berkenaan dengan etika kaum perempuan menjadi seorang istri ${ }^{13}$ serta pemosisian kaum perempuan pada

10 'Âdil Fathi Abdullâh, Kayf Taksabina Qalb Zawjak wa Turdlina Rabbak, (Iskandariyah: Dâr al-îman li Thab’i wa Nasyr wa Tawzî', 2002), h. 12-25

${ }^{11}$ Syaykh Nawawî al-Bantanî, 'Uqûd al-Lujjayn fî Bayânî $\underline{H} u q \hat{u} q$ al-Zawjayn, (Jakarta: Dâr Ihyầ i al-Kutub al-Arabiyyah, t. th).

${ }^{12}$ Syaykh Nawawî al-Bantanî, 'Uqûd al-Lujjayn, h. 3-6.

${ }^{13}$ Syaykh Nawawî al-Bantanî, 'Uqûd al-Lujjayn, h. 6-12 
urusan domestik. ${ }^{14}$ Tentu hal yang demikian tidak lantas menjadi kelemahan etika keluarga dalam Islam karena sudah terbukti bahwa sistem etika ini mampu menghasilkan generasi yang lebih baik dari kenyataan saat ini. Namun, laju dinamika masyarakat yang terus berjalan membentangkan jarak psikologis masyarakat dengan doktrin-doktrin keagamaan semacam itu. ${ }^{15}$

\section{Dilema Kontemporer: Kitab Klasik atau Feminisme Liberal?}

Penulis memiliki tiga hipotesis bahwa, pertama, persoalan ini berkenaan dengan status Hadis-hadis yang kerap dijadikan rujukan. Keberadaan Nabi sebagai sumber hukum, di satu saat menjadi keuntungan bagi umat Islam kala itu karena mereka dengan leluasa bisa mengonsultasikan semua persoalan mereka dan menemukan jawaban pastinya secara langsung dari Nabi, tanpa harus menguji validitas Hadis atau otentisitas sanad seperti harus dilakukan oleh ulama di masa setelahnya. Namun, pada saat bersamaan, konsentrasi pada penulisan Alquran (dan tentunya mengabaikan penjelasan-penjelasan dalam Hadis) membuat penulisan Hadis dan sistem periwayatannya sebagai penjelas redaksi Alquran yang global menjadi terbengkalai.

Absennya persyaratan yang ketat dalam penulisan Hadis ini memunculkan penggelembungan yang mengherankan berkenaan dengan jumlah Hadis yang ada. ${ }^{16}$ Artinya, bukan tidak mungkin bahwa mengenai satu persoalan terdapat ribuan Hadis yang sama dengan jalur yang berbeda-beda, atau redaksi yang berbeda melalui jalur yang beragam. Hal ini turut menyebabkan munculnya interpretasi yang bervariasi dalam menyikapi problem keagamaan. Variasi yang dimaksud tidak hanya berkenaan dengan pemahaman-pemahaman yang bertentangan satu sama lain, tapi bahwa tidak semua Hadis yang ada memiliki otentisitas dan akurasi pemaknaan yang tepat, namun kerap dijadikan dalil dalam menegaskan status hukum banyak kasus.

Dalam hal ini, kritik sanad dan matan Hadis menjadi suatu kemestian, seperti sudah lazim dengan istilah

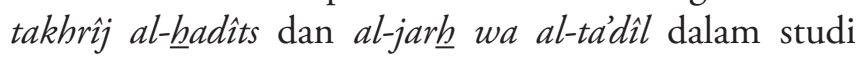

\footnotetext{
${ }^{14}$ Syaykh Nawawî al-Bantanî, 'Uqûd al-Lujjayn, h. 13-16

15 'Ali Jam'ah Muhammad, al-Tharîq ila al-Turâts al-Islâmî, (Bayrût: Nahdlatu Mishr, 2008), h. 189

${ }^{16}$ Tuduhan serupa ini pernah dikemukakan oleh seorang orientalis bernama Jospeh Schacht, bahwa Sunah tidak berakar pada tradisi Nabi Muhammad, melainkan ciptaan Syafi'i melalui seleksi riwayat-riwayat yang disesuaikan dengan prinsip-prinsip yang ia buat. Joseph Schacht, The Origins of Muhammadan Jurisprudance, (Oxford: The Clarendon Press, 1975), h. 77. Bandingkan dengan Akhmad Minhaji, Kontribusi Pembentukan Hukum Islam, Kontribusi Joseph Schacht, (Yogyakarta: UII Press, 2001), h. 24-25
}

kritik Hadis. ${ }^{17}$ Namun, langkah ini tidak bisa menjadi satu-satunya solusi mengingat persoalan ini tidak hanya berkait dengan persoalan otentisitas riwayat dan kebenaran muatannya. Oleh karenanya, dua hipotesis selanjutnya bisa melengkapi langkah pertama ini.

Hipotesis kedua adalah bahwa keberjarakan itu disebabkan oleh banyaknya penafsiran mengenai ayat-ayat dan Hadis-hadis seputar hubungan rumah tangga yang mayoritas ditulis oleh ulama laki-laki sehingga wajar jika terdapat bias gender dalam karyakarya tersebut. ${ }^{18}$ Selain itu, teks-teks mengenai hal ini selalu dalam redaksi global dan mengandaikan posisi seorang laki-laki sebagai suami adalah posisi ideal karena figur yang memerankannya adalah Nabi sendiri, sebagai suami, saat berpesan kepada istri-istrinya, juga mengajarkan etika yang ideal dalam rumah tangga kepada orang-orang muslimat.

Sekali lagi, figur suami ideal diperankan langsung oleh Nabi sehingga jelas bahwa pengajaran etika pasti ditujukan kepada para istri dengan segenap ketidakidealan mereka. Hal ini tertera dalam sebuah Hadis yang dikutip oleh Syaykh Nawawi bahwa, "Akulah orang yang paling ideal di antara kalian dalam urusan keluarga."19 Tampaknya, pernyataan ini tidak diurai dengan seksama oleh para ulama yang menulis etika keluarga semacam ini. Secara tidak langsung mereka, sebagai figur laki-laki dan berposisi sebagai suami, memosisikan dirinya dalam keidealan seorang Nabi, tanpa meneliti kelaikan mereka dalam posisi tersebut.

Dengan kata lain, posisi suami dalam doktrin fikih adalah posisi yang sudah ideal dan tidak perlu diperdebatkan, seideal posisi Nabi yang memerankan figur suami dalam keluarganya. Sementara posisi perempuan sebagai istri sekaligus obyek dari penetapan etika suami-istri berada dalam titik tidak ideal. Sudah menjadi kemestian, ketika teks-teks semacam itu ditafsirkan akan lahir etika-etika yang memarjinalkan kaum perempuan.

Meminjam analisis Wael B. Hallaq, dalam hal ini

17 Takhrîj al-háaîts berarti menampilkan seluruh perawi dan beragam redaksi riwayat dalam tema yang sama untuk mengetahui asal-usul riwayat Hadis yang diteliti secara keseluruhan dan bisa mengetahui adanya Hadis yang sama (dari kalangan sahabat, disebut syâhid), atau semakna (dari kalangan selain sahabat, disebut muttabi). Sedangkan al-jar $\underline{h}$ wa al-tádîl adalah penilaian atas cacat atau adilnya seorang periwayat menggunakan istilah-istilah tertentu yang bersifat hirâkis. Majid Khon, Bustamin, dan Abdul Haris, Ulumul Hadis, (Jakarta: Pusat Studi Wanita UIN Syarif Hidayatullah Jakarta, 2005), h. 188-189, dan 100-101.

${ }^{18}$ Martin Van Bruinessen, Kitab Kuning dan Perempuan, Perempuan dan Kitab Kuning, makalah disampaikan di dalam seminar "Wanita Islam Indonesia dalam Kajian Tekstual dan Kontekstual", diselenggarakan oleh INIS dan Departemen Agama, Jakarta, 2-5 Desember 1991.

${ }^{19}$ Syaykh Nawawi al-Bantani, 'Uqûd al-Lujjayn, h. 4. 
terjadi dua proses dalam penafsiran-penafsiran Hadis yang demikian, proses dissosiasi ${ }^{20}$ yaitu pemisahan para ulama penulis kitab-kitab ini dari generasi sebelumnya, dalam hal ini Nabi sebagai pemeran suami dalam teks, sehingga mereka memosisikan dirinya seideal peranan Nabi, dan proses argumentasi, ${ }^{21}$ bahwa mereka juga memiliki idealitas yang sama untuk memangku "otoritas ideal" tersebut dalam menentukan etika dalam keluarga, dengan modal menguatkan posisi ideal Nabi.

Otoritarianisme semacam ini banyak berkembang dalam mazhab-mazhab fikih yang ada, dilakukan oleh para pengikut suatu mazhab untuk menguatkan posisi imamnya di satu sisi, dan mengambil otoritas imamnya untuk bertindak pada posisi yang sama. Dapat dijadikan

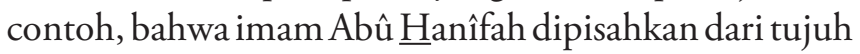
ulama Kufah yang melatarbelakangi lahirnya mazhab

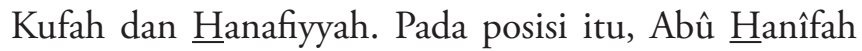
seakan muncul secara tiba-tiba sebagai penyempurna dan sosok ideal bagi masyarakat Kufah, dan menjadi figur yang memiliki otoritas dalam hukum, dengan menafikan peranan guru-gurunya seperti $\underline{\text { Hammâd dan }}$ an-Nakhầî.

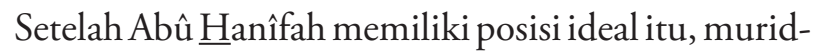
muridnya menghasilkan karya-karya yang menguatkan

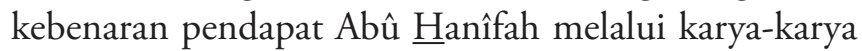
syarh dan penjelasan detail tentang pendapat Abû Hanîfah, yang sebenarnya juga merupakan buah pikir dari generasi sebelumnya. Pada titik itu, generasi murid

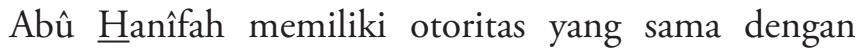
gurunya, dengan catatan ia menguatkan idealitas posisi sang guru, sehingga terkesan bahwa mereka berdiri pada pondasi yang kokoh.

Hal serupa, namun tidak sepenuhnya, terjadi dalam kasus penulisan karya-karya dalam etika keluarga Islam yang mengacu pada Hadis-hadis Nabi. Dalam hal ini proses dissosiasi tidak berarti menonjolkan peranan Nabi sebagai figur ideal dengan mengabaikan posisi generasi sebelum Nabi. Hal ini disebabkan oleh posisi Nabi sebagai sumber kedua hukum Islam, sehingga otoritasnya tidak perlu mengandaikan adanya figur ideal yang akan diserobotnya, seperti dalam contoh mazhab Hanafî di atas. Proses dissosisasi terjadi pada pemahaman bahwa posisi dan figur suami dalam etika keluarga Islam sudah menjadi kebenaran apriori yang tak terbantah, dengan mengabaikan syarat yang harus dipenuhi sebagai figur suami yang ideal.

Setelah idealitas figur suami menjadi kebenaran

${ }^{20}$ Wael B. Hallaq, Authority, Continuity, and Change in Islamic Law, (Cambridge: Cambridge University Press, 2001) h. 27.

${ }^{21}$ Zezen Zainal Muttaqin, "Khaled M. Abou el-Fadl dan Persoalan Otoritas dalam Hukum Islam", dalam Jaenal Aripin (ed.), Filsafat Hukum Islam dalam Dua Pertanyaan, (Jakarta: UIN Press, 2009), h. 137 apriori, gelombang kemunculan kitab-kitab syar $\underline{h}$ menjadi media argumentasi atas pendapat tersebut. Secara otomatis, para ulama yang demikian mengambil otoritas Hadis-hadis yang terkait untuk menguatkan pendapat mereka seputar etika suami-istri. Maka terjadilah pemahaman yang terkesan misoginis dan otoriter.

Hipotesis ketiga adalah dinamika sosial saat ini secara otomatis menjadi jarak psikologis-epistemologis antara generasi umat Islam dengan tradisinya. Selain disebabkan oleh kurangnya pemahaman tentang doktrin-doktrin semacam itu, munculnya gerakan feminisme sejak akhir abad XX menjadi bukti bahwa kaum perempuan mengalami kemajuan dan sudah melakukan lompatan strata sosial dalam masyarakatnya. Sudah barang tentu, doktrin seperti di atas tidak akan mendapat perhatian yang selaiknya dari generasi umat masa kini.

Dengan latar belakang yang demikian, pengkajian kitab klasik mengenai doktrin-doktrin seperti itu masih berlaku di sebagian kalangan, terutama di kalangan pesantren. Sementara kalangan di luar pesantren, sekaligus kalangan yang lebih luas tidak mengenal doktrin itu dan termakan oleh budaya liberal yang diteriakkan oleh gelombang globalisasi budaya barat. Akhirnya muncullah problem besar yang tidak mudah ditangani, seperti uraian di awal.

Pada titik ini, penulis menemukan paradoks dalam dua kenyataan itu: kenyataan dunia pesantren tidak menerima doktrin misoginis dalam kitab-kitab klasik itu secara mentah-mentah. Mereka sudah melakukan penafsiran-penafsiran yang memberi keluwesan dalam kehidupan praktis mereka. ${ }^{22}$ Tentu kenyataan itu cukup membanggakan. Tetapi, dalam tinjauan kalangan berbeda, upaya itu merupakan gerak berputar yang tidak memberi kemajuan berarti bagi perkembangan masyarakat yang sudah teralienasi dalam tahapan dinamika sosial seperti saat ini.

Penafsiran-penafsiran dunia pesantren terhadap doktrin misoginis hanya berupa tepisan pembenaran untuk otoritas teks yang dibaca, sekaligus penolakan atas hegemoni patriarkal dalam waktu yang bersamaan. Walau begitu, teks-teks itu tetap menjadi rujukan utama dalam etika suami-istri. Tegasnya, ada konflik batin di kalangan pesantren saat membaca karya-karya tersebut, tetapi mereka menyadari akan pentingnya karya itu sebagai pijakan yang diwariskan antargenerasi dan

22 Perhatikan pandangan Sinta Nuriyah Wahid dalam tulisannya, "Dekonstruksi Peran Gender di Masyarakat Plural", Makalah Pelatihan Resolusi Konflik se-Indonesia, yang diadakan FORMADINA (Forum Mahasiswa Ushuluddin Se-Indonesia) di Gedung LPTQ, Bandung, Selasa, 21 Agustus 2007. 
bermuatan religius. Akibatnya, terjadi pembaruan yang tidak produktif dan hanya menjadi gerak berputar.

Kenyataan dunia luar pesantren tidak mengalami alienasi dengan doktrin semacam itu, tetapi dengan kenyataan yang harus mereka hadapi. Kebebasan yang mereka perjuangkan justru membawa mereka ke liang kehancuran. Sementara putusnya hubungan mereka dengan doktrin keagamaan tidak memberi mereka pola alternatif selain melanjutkan pola kebebasan yang mulai mengakar, dan kalau pun mereka menyadari kehadiran doktrin keagamaan, yang terkesan dalam benak mereka adalah pemerkosaan atas hak-hak dan kemerdekaan kaum perempuan, sama seperti saat mereka memahami doktrin jihad sebagai ajaran terorisme.

Akan tetapi, dengan menghayati paradoks yang terjadi antara masyarakat pesantren dan non-pesantren, dalam arti yang tidak memiliki akses dan jauh dari doktrin keagamaan, melanjutkan logika doktrin agama menjadi langkah yang lebih positif, sesuai dengan fungsi syariat. Sebab, secara etimologis syariah berarti "menandai atau menggambar jalan yang jelas menuju sumber mata air". Maksud "jalan menuju sumber mata air" adalah jalan ke sumber pokok kehidupan. Dalam penggunaannya yang bersifat keagamaan, kata ini berarti "jalan kehidupan yang baik, yaitu nilai-nilai agama yang diungkapkan secara fungsional dalam makna yang kongkrit". ${ }^{23}$

Dalam pengertian Hossein Nasr, syariat adalah hukum tuhan, yaitu merupakan pelembagaan kehendak-Nya, dengan mana manusia harus hidup secara pribadi dan bermasyarakat. ${ }^{24}$ Dalam pengertian ini, jelas syariah mengatur baik aspek individual maupun aspek sosial dengan landasan tauhid. Oleh karenanya, syariat menjadi sesuatu yang penting, mengingat keberadaannya akan menjadi tonggak bagi penganut agama untuk menggapai kebahagiaan di dunia dan akhirat, terjamin hak kehidupannya dan terpenuhi kebutuhan rohaninya.

Sementara itu, logika masyarakat "liberal" tidak akan menghasilkan apa-apa selain kehancuran, setelah semua nilai diragukan dan tidak ada lagi nilai-nilai yang berlaku. Akan tetapi, pilihan ini tidak lantas mengembalikan kajian doktrin keagamaan pada porsinya semula. Seperti ditekankan di atas, ada alienasi antara teks doktrin yang dibaca dengan pembacanya, namun di saat bersamaan teks itulah panduan menuju kerukunan rumah tangga dan syarat sukses dalam membangun generasi

${ }^{23}$ Ibn Manzhur, Lisân al-Arab, Juz X, (Mishr: al-Mu’assasah alMishriyyah al-'Âmmah li al-Ta’liff wa al-Anba' wa al-Da’wah, t. th), h. 40-44

${ }^{24}$ Sayyed Hossein Nasr, Islam dalam Cita dan Fakta, terj. Abdu rahman Wahid dan Wahid Hasyimi, (Jakarta: Leppens, 1983), h. 60 yang beriman dan berpengetahuan. Dengan begitu, yang perlu dilakukan adalah pemahaman ulang atas doktrin keagamaan, yang dalam perjalanan sejarahnya mengalami distorsi di sana-sini.

Sikap seperti ini adalah penegasan bahwa kajian kritis ini tidak bertujuan untuk menjungkirbalikkan doktrin keagamaan yang ada, melainkan merumuskan ulang pemahaman keagamaan dengan membuang semua bias yang terjadi, baik dilakukan secara sengaja dengan motif politik misalnya, atau merupakan konsekuensi logis dari kecenderungan epistemologis yang mendissosiasi dan mengargumentasi pemikiran keagamaan dan akhirnya melahirkan otoriteranisme dalam pemahaman agama.

Selain itu, sebuah doktrin keagamaan tidak mungkin memiliki keberpihakan gender dan mendiskreditkan golongan tertentu karena agama diturunkan sebagai rahmat bagi seluruh alam, tanpa kecuali. Atas dasar itu, bias yang terjadi dengan latar belakang apapun harus diteliti lebih jauh untuk menemukan titik distorsi sekaligus mencari titik relevansinya dengan kebutuhan masa kini.

\section{Penutup}

Sebagai jembatan antara teks-teks keagamaan dan penganutnya, keberadaan kitab dan karya-karya para ulama perlu diperhatikan karena selain memberikan penjelasan atas kerumitan-kerumitan yang tidak terjangkau oleh masyarakat awam (bukan mujtahid) juga merupakan sebuah interpretasi atas teks sesuai konteks di mana sang pengarang hidup. Kenyataan ini menandakan penerapan doktrin keagamaan bisa saja berbeda-beda sesuai historisitas dan lokalitasnya. Terlebih dengan mengetahui praktik penyelesaian dan persoalan yang terjadi di masa Nabi, akan dirumuskan suatu prinsip etika. Setelah itu, prinsip tersebut akan dikontekstualisasi pada kenyataan yang dihadapi di masa kini, untuk menemukan etika "praktis" untuk saat ini.

Seperti laporan Martin van Bruinessen, Nawawî alBantanî adalah ulama Indonesia yang menjembatani doktrin-doktirn Islam, terutama mazhab Syâfi'î dengan umat Islam Indonesia. ${ }^{25}$ Banyak karya-karyanya berikut anotasinya menjadi bacaan wajib di pelbagai pesantren Nusantara yang berlangsung hingga saat ini. Termasuk di dalamnya Uqûd al-Lujjayn, yang secara tipikal menjelaskan etika suami-istri, berbeda dengan qurrah al-uyûn yang lebih pada etika dalam melakukan hubungan suami-istri.

Sekalipun karya-karya Nawawî saat ini menuai

${ }^{25}$ Martin Van Bruinessen, Kitab Kuning, Pesantren dan Tarekat: Tradisi-Tradisi Islam di Indonesia, (Bandung : Mizan, 1995), h. 122 
banyak kritik, hal itu tidak mengindikasikan bahwa 'Uqûd al-Lujjayn dan karya-karyanya yang lain tidak dikaji lagi. ${ }^{26}$ Bahkan, dengan memosisikan kitab ini sebagai interprestasi kultural-historis, penulis menemukan rumusan etika keluarga yang baru dan emansipatoris.

Lalu bagaimana langkah membaca kitab ini secara proporsional? Di sini perlu menekankan pendekatan sosiologis-historis. Sosiologi sebagai perjalanan ideologi yang meruang, yang memiliki konteksnya yang unik, dan sejarah sebagai perjalanan ideologi yang mewaktu dan dinamis.

Dari penekanan ini ditegaskan bahwa obyek merupakan subjek yang hidup dan berkembang. Ia bukanlah perlintasan ideologi yang bisa semaunya dikendalikan oleh peneliti yang tidak jarang melihat hubungan antara teori dan realitas secara kausalistik, bahwa realitas dipengaruhi oleh teori, atau teori (dalam obyek) dipengaruhi oleh realitas secara linear. Penekanannya adalah, perubahan dan pengubahan yang dilakukan oleh obyek merupakan strategi mereka dalam menghadapi dinamika sosial.

Pembacaan serupa ini menempatkan dua subyek secara bersamaan. Subyek pertama adalah si pengarang. Hal itu disebabkan seorang pengarang memiliki epistemologi yang dilatarbelakangi oleh ideologi tertentu dalam karyanya. Adapun subyek kedua adalah si pembaca, yang memiliki tingkat kerumitan dan problematik yang unik dibanding pengalaman si pengarang, juga pengalaman masyarakat lainnya.

Namun, yang menarik adalah ketika si pembaca merupakan komunitas pembaca karya-karya si pengarang, atau dalam bentuk konkretnya, si pembaca merupakan penganut mazhab si pengarang, atau terikat dalam satu mazhab dengannya. Dalam posisi seperti itu, kita tidak bisa menyebut bahwa si pembaca masih menganut atau sudah membangkang dari doktrin sang pengarang. Tidak bisa juga disebutkan bahwa doktrin tersebut masih atau sudah tidak relevan dengan konteks kehidupan si pembaca. ${ }^{27}$

Inilah yang dimaksud sebagai strategi dalam menghadapi realitas sosial. Dengan kata lain, nilainilai yang dituangkan dalam karya-karya klasik tetap

${ }^{26}$ Hampir semua kritikus fikih wanita di Indonesia mengacu pada 'Uqûd al-Lujjayn sebagai pijakan kritiknya. Di antaranya adalah Masdar F. Mas'udi, Sinta Nuriyah Wahid, Budhy Munawar Rachman. Baca: Sinta Nuriyah Wahid, Dekonstruksi Peran Gender di Masyarakat Plural, Martin Van Bruinessen, Kitab Kuning dan Perempuan, dan Budy Munawar Rachman, Islam dan Feminisme.

${ }_{27}$ Dalam kondisi seperti itu, sebenarnya antara pembaca dan pengarang terdapat keidentikan eksistensial, hanya dibedakan oleh detail kenyataan yang unik pada masing-masing periode. Kesatuan itu dapat diibaratkan bahwa si pembaca merupakan sang pengarang di kekinian pembaca, dan sang pengarang adalah si pembaca di dipedomani oleh masyarakat pembacanya, tanpa terikat pada pengamalan formalistik seperti dibayangkan oleh para kritikusnya selama ini, juga tanpa adanya penolakan dengan tuduhan yang sama.

Sebatas gambaran tentang pola hubungan suamiistri di Indonesia, Soekarno menggambarkan dalam bukunya, Sarinah, bahwa salah besar jika perempuanperempuan Indonesia dipengaruhi dan mengikuti pola pikir feminisme liberal, mengingat situasi sosial yang dihadapi berbeda. Indonesia tidak pernah mengenal pembedaan antara laki-laki dan perempuan, secara parokial seperti dalam sejarah perempuan Eropa, terkecuali pada segelintir komunitas priyayi dan kelas menengah. ${ }^{28}$ Adapun mayoritas bangsa Indonesia masih berada pada taraf menengah ke bawah, atau justru cenderung miskin. Sehingga, pembedaan serupa itu merupakan hal yang sangat mustahil terjadi.

Atas logika itu, pada dasarnya keprihatinan kondisi rumah tangga di era kontemporer ini tidak perlu ditarik pada persoalan internasional, atau isu-isu global persamaan hak laki-laki dan perempuan. Sebab hal itulah yang menimbulkan dua lapis keterasingan masyarakat. Pertama, ketika ia menolak doktrin agamanya, demi kebebasan yang menyebabkan dirinya tersekulerkan. Kedua, ketika kenyataan sekuler tidak mengubah kenyataan menjadi lebih baik, justru sebaliknya, ia kembali teralienasi dari kenyataannya.

Namun, bukan perkara mudah untuk kembali kepada doktrin agama, berkenaan dengan hukum keluarga, sebab masyarakat sudah terlanjur tersekulerkan. Di sinilah pentingnya paradigma yang saya tegaskan di atas, yaitu kembali menjadi komunitas pembaca bagi karya-karya klasik. Mengingat masyarakat kita adalah masyarakat pekerja, baik laki-laki maupun perempuannya, tidak akan ada konflik seperti keluhan gerakan feminis liberal. Dan pada saat itulah doktrin klasik, perlu dipedomani kembali, yaitu prinsip-prinsip yang lebih mengedepankan pada kehidupan harmonis antara suami-istri.

Sudah barang tentu, cara memahaminya, seperti telah diuraikan, bahwa posisi perempuan memang ditempatkan sebagai figur yang tidak ideal, mengingat doktrin itu ditujukan pada istri-istri Nabi yang menjadi

kekinian sang pengarang. Jauh berbeda, ketika seseorang belajar dari epistemologi barat yang tidak ada keterkaitan ideologis dengan para pemikirnya. Perubahan dan pengubahan nilai-nilai sosial harusnya dilihat dari hubungan eksistensial tersebut. Yaitu untuk menghindari ketercerabutan kultural seperti digelisahkan di awal tulisan ini. Perhatikan ulasan serupa ini dalam Muhammad Ẩbid al-Jâbirî, Nahn wa Turâts; Qirâah Mu'âshirah fi Turâtsina al-Falsafi, (Dâr Baidâ: alMarkaz al-Tsaqâfi al-'Arabî, 1986), h. 11-53.

${ }^{28}$ Soekarno, Sarinah; Kewadjiban Wanita dalam Perdjoangan Republik Indonesia, cet. III, (Djokjakarta (an sich): Panitia Penerbit Buku-buku Karangan Presiden Soekarno, 1963), h. 261-262. 
obyek “dakwah" Nabi yang ideal. Artinya, ketidakidealan itu selalu mengandaikan perilaku membangkang seorang istri kepada suaminya, bukan karena sudah (atau selalu) dilakukan oleh sang istri, atau sebagai sifat yang melekat sebagai karakter seorang istri. Dengan begitu, di satu sisi doktrin hukum keluarga Islam ini dimaksudkan sebagai pencegahan bagi istri untuk menimbulkan keretakan dalam rumah tangganya. Pada sisi lain, doktrin tersebut merupakan anjuran bagi para suami untuk menjadi suami yang ideal, seideal Nabi memerankan figur suami dan kepala rumah tangga bagi istri dan keluarganya.

Pemahaman yang utuh dari doktin hukum keluarga Islam, dengan demikian, menempatkan suami-istri pada posisi setara, jika masing-masing pihak melakukan kewajibannya, istri yang memenuhi kewajibannya, dan suami yang berusaha menjadi suami yang ideal. Sekali lagi, idealitas seorang suami dan istri bukanlah pemantapan karakter atau istri, bahwa suami selalu ideal dan istri selalu tidak ideal. Islam menginginkan adanya harmoni dalam hubungan rumah tangga. Menjadi sangat tidak logis jika doktrin tersebut dipahami secara liberal menjadi doktrin yang antifeminisme atau cenderung pada budaya patriarkal. []

\section{Pustaka Acuan}

'Abd Allâh, 'Âdil Fathi, Kayfa Taksabina Qalba Zawjaki wa Turdlinna Rabbaki, Iskandariyah: Dâr al-îman li Thab'i wa Nasyr wa Tawzî̀, 2002.

Absîhî, al-, Syihâb al-Dîn ibn Ahmad Abî al-Fath̆, AlMustatraffi Kull Fan Mustažraf, Juz I, Bâyrut: Dâr al-Kutub al-Ilmiyah, 1993.

Amîn, Husayn, al-Mar'ah bayna al-Syâri' wa al-Bayti, Bayrût: Dâr al-Syurûq, 1999.

Bantanî, al-, Syaykh Nawawî, Uqûd al-Lujjayn fî Bayâni $\underline{H} u q \hat{u} q$ al-Zawjayn, Jakarta: Dâr Ihyầi al-Kutub al'Arabiyyah, t.th.

Boore, C. George, Sejarah Psikologi dari Masa Kelahiran Sampai Masa Modern, terj. Abdul Qadir Saleh, cet. II, Yogyakarta: Primasophie, 2007.

Bruinessen, Martin Van, Kitab Kuning dan Perempuan, Perempuan dan Kitab Kuning, makalah disampaikan di dalam seminar "Wanita Islam Indonesia dalam Kajian Tekstual dan Kontekstual", diselenggarakan oleh INIS dan Departemen Agama, Jakarta, 2-5 Desember 1991.
-, Kitab Kuning, Pesantren dan Tarekat; TradisiTradisi Islam di Indonesia, Bandung : Mizan, 1995.

Hallaq, Wael B., Authority, Continuity, and Change in Islamic Law, Cambridge: Cambridge University Press, 2001.

Ibn Manzhûr, Lisân al-'Arab, Juz X, Mesir: al-Mu'assasah al-Misriyah al-'Ammah li al-Ta'lîfi wa al-Anba' wa al-Da'wah, t. th.

Jâbirî, al-, Muhammad 'Âbid, Nahnn wa Turâts: Qirẩah Mu'âshirah $f i$ Turâtsina al-Falsafí, Dâr Baidâ: alMarkaz al-Tsaqâfi al-Arabî, 1986.

Jurjâni, al-, Kitab al-Ta'rîfât, Bayrût: Maktabah Libanon, 1969.

Khon, Majid, Bustamin, dan Abdul Haris, Ulumul Hadis, Jakarta: Pusat Studi Wanita UIN Syarif Hidayatullah Jakarta, 2005.

Minhaji, Akhmad, Kontribusi Pembentukan Hukum Islam, Kontribusi Joseph Schacht, Yogyakarta: UII Press, 2001.

Morteza Mutahari, The Human Being in The Qur 'an, Teheran: Islamic Propogation Organitation, 1984.

Muhammad, 'Alî Jam'ah, al-Tharîq ilâ al-Turâts alIslâmî, Bayrût: Nahdhah al-Mishr, 2008.

Muttaqin, Zezen Zainal, Khaled M. Abou el-Fadl dan Persoalan Otoritas dalam Hukum Islam, dalam Jaenal Aripin (ed.), Filsafat Hukum Islam dalam Dua Pertanyaan, Jakarta: UIN Press, 2009.

Nasr, Sayyed Hossein, Islam dalam Cita dan Fakta, terj. Abdurrahman Wahid dan Wahid Hasyimi, Jakarta: Leppens, 1983.

Rachman, Budy Munawar, Islam dan Feminisme dari "Sentralisme" Kepada Kesetaraan, Makalah. t.th.

Schacht, Joseph, The Origins of Muhammadan Jurisprudance, Oxford: The Clarendon Press, 1975.

Soekarno, Sarinah; Kewadjiban Wanita dalam Perdjoangan Republik Indonesia, cet. III, Djokjakarta (an sich): Panitia Penerbit Buku-buku Karangan Presiden Soekarno, 1963.

Thabarî, al-, Abû Ja'far, Jâmi' al-Bayân fî̀ Ta'wîl alQur'ân, j. III, Bayrût: Mu assasah al-Risâlah, 2000.

Wahid, Sinta Nuriyah, Dekonstruksi Peran Gender di Masyarakat Plural, Makalah Pelatihan Resolusi Konflik se-Indonesia, yang diadakan FORMADINA (Forum Mahasiswa Ushuluddin Se-Indonesia) di Gedung LPTQ, Bandung, Selasa, 21 Agustus 2007. 